\title{
Talimogen laherparepwek (T-VEC) — nowa terapia czerniaków skóry zmodyfikowanym genetycznie wirusem onkolitycznym
}

\author{
Piotr Rutkowski, Marcin Zdzienicki
}

\begin{abstract}
Talimogen laherparepwek (T-VEC) to pierwsza (ostatnio zarejestrowana w Unii Europejskiej) immunoterapia wirusem onkolitycznym, która wykazała korzyść terapeutyczną w leczeniu czerniaka skóry w badaniu klinicznym III fazy, powodując większy odsetek trwałej odpowiedzi na leczenie oraz medianę przeżyć całkowitych, w szczególności w grupie nieleczonych wcześniej chorych w nieresekcyjnym stadium IIIB, IIIC lub IVM1 a. T-VEC był dobrze tolerowany i jest obecnie badany w leczeniu skojarzonym z inhibitorami punktów kontrolnych układu immunologicznego oraz terapii neoadiuwantowej. W pracy omówiono aktualne dane dotyczące skuteczności i bezpieczeństwa tego leku w leczeniu zaawansowanego czerniaka.
\end{abstract}

\section{Talimogene laherparepvec (T-VEC), review of a new therapy of cutaneous melanoma with genetically modified oncolytic virus}

Talimogene laherparepvec (T-VEC) is the first (approved recently in the European Union) oncolytic immunotherapy which demonstrated therapeutic benefit for cutaneous melanoma in a phase III clinical trial. This resulted in a higher that previously obtainable response rate and median overall survival, particularly in untreated patients or those with stage IIIB, IIIC, or IVM1a disease. T-VEC was well tolerated and is currently studied in combined therapy with immunological checkpoints and in a neoadjuvant setting. In the review, current data on its efficacy and safety in melanoma therapy are discussed.

Słowa kluczowe: czerniak, wirus onkolityczny, talimogen laherparepwek

Key words: melanoma, oncolytis virus, talimogene laherparepvec

\section{Wstęp}

Przełomowe w leczeniu uogólnionych czerniaków jest ostatnie 5 lat, co jest związane z rozwojem zarówno leczenia ukierunkowanego molekularnie, jak i immunoterapii [1, 2]. Nowe terapie wprowadzone do codziennej praktyki klinicznej sprawiły, że obecnie sposób postępowania w przypadku stwierdzenia nieresekcyjnego, przerzutowego czerniaka skóry ma niewiele wspólnego z praktyką kliniczną sprzed 5 lat. W grudniu 2015 roku zarejestrowano w Unii Europejskiej nowy sposób leczenia zaawansowanego czerniaka za pomocą zmodyfikowanego genetycznie wirusa onkolitycz- nego - talimogen laherparepwek (T-VEC - talimogene laherparepvec) $[3,4]$. W pracy przedstawiono dane dotyczące wyników badań tej terapii z uwzględnieniem skuteczności w wybranych populacjach oraz bezpieczeństwa u chorych na czerniaki.

\section{Dane farmakologiczne}

Talimogen laherparepwek to pierwszy lek z nowej klasy zmodyfikowanych genetycznie wirusów onkolitycznych (atenuowany wirus opryszczki typu 1 HSV-1 z wprowadzoną sekwencją kodującą dla ludzkiego czyn- 
Tabela I. Podsumowanie wyników badania 005/05 (OPTiM), dotyczącego stosowania T-VEC w populacji ITT (intent-to-treat) zgodnej z zaplanowanym leczeniem

\begin{tabular}{|c|c|c|c|}
\hline & Punkt końcowy badania & T-VEC $(n=295)$ & GM-CSF $(n=141)$ \\
\hline Odsetek trwałej odpowiedzi na leczenie (DRR) & Pierwszorzędowy & $\begin{array}{l}16,3 \%(n=48) \\
(95 \% \text { Cl: } 12,1-20,5) \\
\text { Iloraz szans } 8,9 ;(95 \% \text { Cl: } 2,7-29,2) \\
p<0,0001\end{array}$ & $\begin{array}{l}2,1 \%(n=3) \\
(95 \% \mathrm{Cl}: 0,0-4,5)\end{array}$ \\
\hline $\begin{array}{l}\text { Całkowity odsetek odpowiedzi na leczenie } \\
\text { (\% CR — całkowite remisje, \% PR - częściowe } \\
\text { remisje) }\end{array}$ & Drugorzędowy & $\begin{array}{l}26,4 \%(n=78) \\
(95 \% \text { Cl: } 21,4-31,5 \%) \\
(10,8 \% \text { CR; } 15,6 \% \text { PR) }\end{array}$ & $\begin{array}{l}5,7 \%(n=8) \\
(95 \% \mathrm{Cl}: 1,9-9,5) \\
(0,7 \% \mathrm{CR} ; 5 \% \text { PR) }\end{array}$ \\
\hline Czas przeżycia całkowitego (OS) [mediana] & Drugorzędowy & $\begin{array}{l}23,3 \text { miesiąca }(95 \% \mathrm{Cl}: 19,5-29,6) \\
\text { HR: } 0,79(95 \% \mathrm{Cl}: 0,62-1,00) \\
p=0,051\end{array}$ & $\begin{array}{l}18,9 \text { miesiąca } \\
(95 \% \mathrm{Cl}: 16,0-23,7)\end{array}$ \\
\hline $\begin{array}{l}\text { Czas utrzymywania się odpowiedzi na } \\
\text { leczenie (utrzymująca się odpowiedź podczas } \\
\text { ostatniego badania guza) [mediana] }\end{array}$ & Drugorzędowy & $\begin{array}{l}\text { Nie osiągnięto mediany } \\
\text { (zakres: od >0,0 do > 16,8 } \\
\text { miesiąca) } \\
\text { HR: } 0,46(95 \% \text { Cl: } 0,35-0,60)\end{array}$ & $\begin{array}{l}\text { 2,8 miesiąca } \\
\text { (zakres: (od }>1,2 \text { do }>14,9 \\
\text { miesiąca) }\end{array}$ \\
\hline Czas do wystąpienia odpowiedzi [mediana] & Drugorzędowy & 4,1 miesiąca & 3,7 miesiąca \\
\hline $\begin{array}{l}\text { Czas do momentu stwierdzenia niepowodzenia } \\
\text { leczenia [mediana] }\end{array}$ & Drugorzędowy & $\begin{array}{l}8,2 \text { miesiąca } \\
(95 \% \mathrm{Cl}: 6,5-9,9) \\
\text { HR: } 0,42(95 \% \mathrm{Cl}: 0,32-0,54)\end{array}$ & $\begin{array}{l}2,9 \text { miesiąca } \\
(95 \% \mathrm{Cl}: 2,8-4,0)\end{array}$ \\
\hline
\end{tabular}

OS (overall survival) — przeżycia całkowite; Cl (confidence interval) — przedział ufności; HR (hazard ratio) — iloraz hazardu

nika stymulującego tworzenie kolonii granulocytów i makrofagów (GM-CSF — granulocyte macrophage colony-stimulating factor), który podawany jest doguzowo i ulega selektywnej replikacji wewnątrz nowotworu, produkując GM-CSF o właściwościach immunostymulujących [3, 4]. Talimogen laherparepwek powoduje śmierć komórek nowotworowych i uwolnienie antygenów nowotworowych. Uważa się, że wraz z GM-CSF pobudza on ogólnoustrojową przeciwnowotworową odpowiedź immunologiczną i odpowiedź efektorowych limfocytów T. Myszy, u których po leczeniu uzyskano całkowitą regresję guza pierwotnego, były odporne na powtórne próby wszczepienia nowotworu. Modyfikacja cząsteczki HSV-1 w celu uzyskania T-VEC polega między innymi na delecji ICP34.5 oraz ICP47. Antywirusowa odpowiedź immunologiczna zabezpiecza prawidłowe komórki po zainfekowaniu T-VEC.

Po miejscowym wstrzyknięciu do zmiany nowotworowej T-VEC wychwytywany jest przez receptory HSV-1 znajdujące się na komórkach nowotworowych i prawidłowych. Ze względu na to, żeT-VEC jest wstrzykiwany bezpośrednio doogniskowo i tam replikuje, biodostępność i jego stężenie w krążeniu systemowym nie są predyktorami aktywności leku - z tego powodu nie były one badane. Talimogen laherparepwek jest zasadniczo usuwany z organizmu przez mechanizmy obronne gospodarza (np. w procesie autofagocytozy i adaptacyjnej odpowiedzi immunologicznej). Na podstawie wyników międzyokresowej analizy danych 30 pacjentów wykazano, że DNA T-VEC było wykrywane przemijająco w niskich stężeniach we krwi u 90\% pacjentów i w moczu u 20\% pacjentów uczestniczących w badaniu.

\section{Skuteczność terapii w badaniach klinicznych}

W badaniu II fazy na 50 chorych na czerniaka w stopniu IIIC-IVC odsetek odpowiedzi wyniósł $26 \%$, a regresje dotyczyły zarówno zmian poddanych iniekcji, jak i przerzutów odległych, gdzie nie podawano T-VEC. U 92\% chorych utrzymywały się one przez długi czas w zakresie 7-31 miesięcy [5].

W badaniu III fazy 005/05 (OPTiM) z losowym doborem chorych 436 pacjentów w stadium IIIB, IIIC i IVM1a, niekwalifikujących się do resekcji chirurgicznej, przydzielono do terapiiT-VEC lub iniekcji podskórnych GM-CSF [6].Z udziału w badaniu wykluczono pacjentów z aktywnymi przerzutami do mózgu, przerzutami do kości, z rozległym naciekaniem narządów jamy brzusznej, pierwotnym czerniakiem gałki ocznej lub błon śluzowych, z objawami niedoboru odporności lub stosujących ogólnoustrojowo leki przeciwwirusowe. Pacjentów leczono przez co najmniej 6 miesięcy lub do czasu eliminacji wszystkich zmian, które można ostrzykiwać.

Głównym punktem końcowym badania był odsetek długotrwałych odpowiedzi (DRR $\geq 6$ miesięcy), badanie to wykazało istotną korzyść z zastosowania T-VEC w porównaniu z GM-CSF (DRR 16,3\% vs 2,1\%). Odsetek odpowiedzi ogółem wyniósł $26,4 \%$ w ramieniu z T-VEC, a mediana OS -23,3 miesiąca (tab. I). Najlepsze wyniki przy zastosowaniu T-VEC uzyskano w stopniach IIIB/IIIC/IVM1a.

U 56 chorych (72\%) odpowiadających na leczenie T-VEC odpowiedź utrzymywała się nadal w chwili przeprowadzenia analizy pierwszorzędowej. Dodatkowo stwierdzono, że u 27 z 79 chorych $(34,2 \%)$ stwierdzono zmniejszenie o $\geq 50 \%$ zmian zlokalizowanych poza narządami jamy brzusznej, do których nie podano T-VEC. 
Tabela II. Podsumowanie wyników analizy badawczej w podgrupach, przeprowadzonej w ramach badania 005/05 z T-VEC

\begin{tabular}{lccccc}
\hline & \multicolumn{2}{c}{ DRR (\%) } & \multicolumn{2}{c}{ ORR (\%) } & OS (ryzyko względne) \\
\cline { 2 - 6 } & T-VEC & GM-CSF & T-VEC & GM-CSF & T-VEC w porównaniu z GM-CSF \\
\hline $\begin{array}{l}\text { Stopień IIIB/IIIC/ stopień IVM1a } \\
\text { (T-VEC, } \mathrm{n}=163 ;\end{array}$ & 25,2 & 1,2 & 40,5 & 2,3 & $0,57(95 \%$ Cl: 0,40-0,80) \\
$\begin{array}{l}\text { GM-CSF, } \mathrm{n}=86 \text { ) } \\
\text { Stopień IVM1B/ IVM1C }\end{array}$ & & & & & \\
$\begin{array}{l}\text { (T-VEC, } \mathrm{n}=131 ; \\
\text { GM-CSF, } \mathrm{n}=55 \text { ) }\end{array}$ & 5,3 & 3,6 & 9,2 & 10,9 & $1,07(95 \%$ Cl: $0,75-1,52)$ \\
\hline
\end{tabular}

Klasyfikacja stopnia zaawansowania wg AJCC (American Joint Committee on Cancer), wyd. VI, DRR (durable response rate) — odsetek trwałej odpowiedzi na leczenie, ORR (overall response rate) — całkowity odsetek odpowiedzi na leczenie

Działanie leku było szczególnie widoczne w populacji chorych w stopniach IIIB/IIIC/IVM1a, gdzie mediana OS wyniosła 41,1 miesiąca (95\% Cl:30,6 - niemożliwy do oszacowania; $\mathrm{n}=163$ chorych) dla grupy otrzymującej talimogen laherparepwek w porównaniu z 21,5 miesiąca $(95 \%$ Cl: 17,4-29,6) dla chorych leczonych wyłącznie GM-CSF (tab. II). Różnic w OS nie obserwowano w analizie podgrup IVM1b/IVM1c.

\section{Działania niepożądane}

Leczenie T-VEC jest dobrze tolerowane. Do działań niepożądanych najczęściej ( $\geq 25 \%$ ) zgłaszanych u pacjentów leczonych T-VEC należały: zmęczenie (50,3\%), dreszcze $(48,6 \%)$, gorączka $(42,8 \%)$, nudności $(35,6 \%)$, objawy grypopodobne (30,5\%) oraz ból w miejscu wstrzyknięcia (27,7\%). W 98\% przypadków te działania niepożądane miały nasilenie łagodne lub umiarkowane. Najczęściej występującym działaniem niepożądanym 3 lub wyższego stopnia było zapalenie tkanki podskórnej (2,1\%). Najczęstszym objawem ubocznym terapii T-VEC są objawy paragrypowe.

Po leczeniu T-VEC może wystąpić martwica tkanek lub owrzodzenie w miejscu zmiany nowotworowej W badaniach klinicznych zgłaszano przypadki występowania zaburzeń o podłożu immunologicznym, w tym zapalenia kłębuszków nerkowych, zapalenia naczyń, zapalenia płuc, nasilenia łuszczycy i bielactwa u pacjentów otrzymujących T-VEC.

Lek ten jest przeciwwskazany u pacjentów z silnie obniżoną odpornością. Kobietom w wieku rozrodczym należy zalecić stosowanie skutecznej metody antykoncepcji w celu zapobiegania ciąży w trakcie leczenia T-VEC.

Osoby należące do fachowego personelu medycznego oraz osoby utrzymujące bliski kontakt z chorymi (np. współlokatorzy, opiekunowie, partnerzy seksualni lub osoby śpiące w tym samym łóżku) powinny unikać bezpośredniej styczności z ostrzykiwanymi zmianami lub płynami ustrojowymi leczonych pacjentów w całym okresie leczenia i maksymalnie przez 30 dni po podaniu ostatniej dawki leku. Kobiety w ciąży i osoby z obniżoną odpornością utrzymujące bliski kontakt z chorymi nie powinny zmieniać im opatrunków ani oczyszczać miejsca wstrzyknięcia, aby nie doszło do transmisji wirusa opryszczki.
W badaniach klinicznych u pacjentów leczonych T-VEC zgłaszano przypadki zakażenia wirusem opryszczki (w tym opryszczkę wargową i opryszczkowe zapalenie rogówki), które są wrażliwe na acyklowir.

\section{Status prawny i dawkowanie}

T-VEC (Imlygic ${ }^{\circledR}$ ) został zarejestrowany w Unii Europejskiej i Stanach Zjednoczonych do leczenia dorosłych chorych na nieresekcyjne czerniaki w stadium przerzutów do regionalnych węzłów chłonnych lub przerzutów odległych bez zajęcia kości, mózgu, płuc lub innych narządów wewnętrznych - stopnie IIIB/IIIC/IVM1a. Lek ten podaje się we wstrzyknięciach bezpośrednio do zmian skórnych, podskórnych i/lub w węzłach chłonnych, widocznych, wyczuwalnych palpacyjnie lub pod kontrolą ultrasonograficzną. Powinien być stosowany w pierwszej linii terapii $[3,4]$.

T-VEC jest dostępny we fiolkach o pojemności $1 \mathrm{ml}$ przeznaczonych do jednorazowego wykorzystania, w dwóch różnych stężeniach: $10^{6}$ (1 milion) PFU/ml — wyłącznie dawka początkowa oraz $10^{8}$ (100 milionów) PFU/ml — wszystkie następne dawki. Całkowita objętość wstrzyknięcia podawanego podczas każdej sesji leczenia nie powinna być większa niż $4 \mathrm{ml}$. Zalecana dawka początkowa to maksymalnie $4 \mathrm{ml}$ T-VEC o stężeniu $10^{6}$ (1 milion) PFU/ml. W następnych dawkach należy podawać maksymalnie $4 \mathrm{ml} \mathrm{T-VEC} \mathrm{o} \mathrm{stężeniu}$ $10^{8}$ (100 milionów) PFU/ml — drugą dawkę po 3 tygodniach od pierwszego podania, następnie co 2 tygodnie. Przy pierwszym podaniu należy wstrzyknąć lek w zmianę(-y) największą(-e), a następnie pozostałe; przy kolejnych podaniach należy najpierw wstrzyknąć lek we wszystkie nowe zmiany (które mogły powstać po poprzednim podaniu). W zależności od wielkości zmiany dobiera się odpowiednią objętość T-VEC do wstrzyknięcia.

Przed uzyskaniem odpowiedzi na leczenie T-VEC mogą powiększyć się istniejące zmiany lub mogą pojawić się zmiany nowe (zjawisko pseudoprogresji). Dopóki obecne są zmiany nadające się do ostrzykiwania, należy podawać lek co najmniej przez 6 miesięcy, chyba że — zdaniem lekarza - leczenie nie przynosi pacjentowi korzyści lub konieczne jest inne leczenie. 


\section{Podsumowanie}

Immunoterapia stanowi trzeci rodzaj współczesnego armamentarium $w$ leczeniu systemowym nowotworów złośliwych poza chemioterapią i leczeniem ukierunkowanym molekularnie, o unikalnym mechanizmie działania. T-VEC jest pierwszym przedstawicielem nowej klasy leków - zmodyfikowanych genetycznie wirusów onkolitycznych - który wykazał korzyść terapeutyczną w leczeniu zaawansowanego czerniaka i u części chorych doprowadził do trwałej remisji choroby. W chwili obecnej jego miejsce terapeutyczne nie jest do końca ustalone i ograniczone jest w monoterapii jedynie do nieresekcyjnego stopnia IIIB/C (zwłaszcza zmiany in transit) lub IVA. Konieczne są dalsze badania kliniczne nad tym lekiem (szczególnie ze względu na dobór niestandardowego komparatora w badaniu rejestracyjnym), choć już obecnie trafił on do rekomendacji amerykańskich (NCCN) i europejskich (ESMO) jako opcja terapeutyczna o potwierdzonej skuteczności w terapii zaawansowanych czerniaków [7, 8]. Kontrowersje w badaniu OPTiM budził dobór komparatora, jakim był GM-CSF podawany podskórnie. Wynikało to najprawdopodobniej z rozpoczęcia badania w 2009 roku, przed erą nowoczesnej immunoterapii (i znanych wówczas wyników terapii przeciwciałami anty-CTLA-4 czy anty-PD-1) oraz dostępnych w tym czasie przesłanek o aktywności w leczeniu czerniaka [9]. Stąd wydają się istotne dalsze badania porównawcze nad T-VEC ze współcześnie stosowaną immunoterapią w czerniakach. T-VEC był generalnie dobrze tolerowany, najczęściej obserwowano objawy paragrypowe (osłabienie, dreszcze i gorączka). Obecnie trwają badania nad leczeniem skojarzonym T-VEC $z$ inhibitorami punktów kontrolnych układu immunologicznego (anty-CTAL-4, anty-PD-1, anty-PD-L1, m.in. ipilimumabem i pembrolizumabem), nad jego zastosowaniem w leczeniu neoadiuwantowym, jak również w innych nowotworach złośliwych [10, 11].

Konflikt interesów: Piotr Rutkowski otrzymywał honoraria od Novartis, BMS, GSK, MSD, Roche, służył jako członek Advisory Board dla firmy Novartis, BMS, Amgen; Marcin Zdzienicki uczestniczył w Advisory Board dla firmy Amgen

\section{Prof. dr hab. n. med. Piotr Rutkowski}

Klinika Nowotworów Tkanek Miękkich, Kości i Czerniaków, Centrum Onkologii — Instytut im. Marii Skłodowskiej-Curie w Warszawie

ul. Roentgena 5, 02-781 Warszawa

e-mail:piotr.rutkowski@coi.pl

Otrzymano: 2 lutego $2016 \mathrm{r}$.

Przyjęto do druku: 23 marca 2016 r.

\section{Piśmiennictwo}

1. Rutkowski P. (red.). Złośliwe nowotwory skóry. Gdańsk:Via Medica 2014.

2. Rutkowski P, Wysocki PJ, Nasierowska-Guttmejer A i wsp. Czerniaki skóry - zasady postępowania diagnostyczno-terapeutycznego w 2016 roku. Nowotwory J Oncol 2015; 65: 501-516.

3. Talimogen Laherparepwek. Charakterystyka Produktu Leczniczego 2016.

4. Greig SL. Talimogene Laherparepvec: First global approval. Drugs 2016; 76: 147-154.

5. Senzer NN, Kaufman $\mathrm{HL}$, Amatruda T i wsp. Phase II clinical trial of a granulocyte-macrophage colony-stimulating factor-encoding, second-generation oncolytic herpesvirus in patients with unresectable metastatic melanoma. J Clin Oncol 2009; 27: 5763-5771.

6. Andtbacka RH, Kaufman HL, Collichio F i wsp. Talimogene laherparepvec improves durable response rate in patients with advanced melanoma. J Clin Oncol 2015; 33: 2780-2788.

7. NCCN Clinical Practice Guidelines in Oncology. Melanoma v. 2. 2016.

8. Dummer $\mathrm{R}$ Hauschild $\mathrm{A}$ L Lindenblatt $\mathrm{N}$ i wsp. Cutaneous melanoma: ESMO Clinical Practice Guidelines for diagnosis, treatment and follow-up. Ann Oncol 2015; 26 (Suppl. 5): v126-v132.

9. Kaufman HL, Ruby CE, Hughes T i wsp. Current status of granulocyte-macrophage colony-stimulating factor in the immunotherapy of melanoma. J Immunother Cancer 2014; 2: 11.

10. Johnson DB, Puzanov I, Kelley MC. Talimogene laherparepvec (T-VEC) for the treatment of advanced melanoma. Immunotherapy 2015; 7:611-619.

11. Kohlhapp FJ, Kaufman HL. Molecular Pathways: Mechanism of Action for Talimogene Laherparepvec, a New Oncolytic Virus Immunotherapy. Clin Cancer Res 2016; 22: 1048-1054. 